\title{
А.Б. Скорик
}

\author{
Харківський національний університет Повітряних Сил ім. І. Кожедуба, Харків
}

\section{МЕТОДОЛОГІЧНІ ОСНОВИ СТВОРЕННЯ АРХІТЕКТУРИ ДАТА-ЦЕНТРИЧНОЇ ЕКОСИСТЕМИ ЗЕНІТНОÏ РАКЕТНОÏ СИСТЕМИ}

\begin{abstract}
У статті запропоновано нові підходи до управління життєвим ияиклом ЗРС. Життєвий ичикл системи розглядається як діяльність всіх систем забезпечення, щзо ведуть иільову систему від ї̈ задуму до виведення з експлуатащіï. Наголошується на необхідності інтеграції систем забезпечення у рамках датаиентричної екосистеми ЗРС. Запропоновані підходи до побудови архітектури екосистеми ЗРС, розроблено модель архітектури системи інтеграџії і розвитку можливостей по створенню екосистеми ЗРС і обтрунтована загальна структура методу створення архітектури екосистеми ЗРС.
\end{abstract}

Ключові слова: архітектура, архітектурний фреймворк, дата-цуентрична операчія, дата-цуентрична система, екосистема ЗРС, система забезпечення, управління життєвим цииклом, иільова система.

\section{Вступ}

Постановка проблеми. В процесі життєвого циклу (ЖЦ) відбувається послідовна зміна стану ЗРС. Ці зміни відбуваються в рамках відповідних практик (процесів): визначення вимог до ЗРС, розробки, створення дослідних зразків, серійного виробництва ЗРС, ï експлуатації, утилізації. Всі ці практики здійснюються системами забезпечення: конструкторськими бюро, виробничими підприємствами, військовими частинами [1].

Індустріально розвиненими країнами і ключовими учасниками міжнародного ринку в теперішній час формується нова культура створення і застосування складних систем-систем, заснована на засадах соціокультурних моделей побудови організацій i мультирозумних систем [2].

Перехід до соціокультурних моделей побудови організацій передбачає кардинальну зміну структурної організації і поведінки систем забезпечення. Між ними складаються відносини, що дозволяють казати не про окремі системи забезпечення, а про єдину систему-систем [1] підтримки ЖЦ ЗРС. Така система впродовж свого власного життєвого циклу змінює цілі функціонування, структуру у часі і просторі. Даний підхід дуже близький до підходу по створенню екосистем [3]. Раніше, такий підхід був пов'язаний з побудовою мономіст, що створюються для вирішення якоїсь великої науково-промислової проблеми. Надалі, коли актуальність даної проблеми падала, багато з таких мономіст приходили в занепад, що викликало значні соціальні проблеми. Однак досвід формування навколо цільової системи розвиненої сервісної інфраструктури є дуже важливим. I на сьогоднішній момент цей досвід відроджується, але тільки на ново- му науковому і організаційному рівні.

Зенітна ракетна система 3 моменту її задуму і система-систем підтримки іiі ЖЦ разом утворюють екосистему ЗРС.

Створення екосистеми ЗРС на базі використання сучасних інформаційних технологій дозволить досягти більшого ступеня інтеграції систем підтримки ЖЦ, однак не зажадає великих витрат на інфраструктуру і соціальну сферу, що було необхідно в рамках створення мономіст.

Разом 3 тим слід відзначити, що методологія створення екосистем ЗРС на теперішній час ще не розроблена.

Аналіз останніх досліджень і публікацій. Питання розроблення та впровадження сучасних механізмів управління життєвим циклом озброєння, військової та спеціальної техніки в Україні розглядаються у роботах $[1 ; 4-7]$.

У відомих публікаціях з питань системних досліджень і створення технічних екосистем [3; 8-18] відсутні науково обгрунтовані методи, які б із системних засад вирішували проблему розробки методологічного апарату створення архітектури екосистеми для перспективних ЗРС.

Мета статті полягає в поданні методологічних основ створення архітектури дата-центричної екосистеми ЗРС і управління нею на базі діяльністного (процесного) підходу і концепції дата-центричної операції.

\section{Виклад основного матеріалу}

В теперішній час наукова методологія управління процесами створення озброєння, застосовувана в Україні базується на теорії розробки програм озброєння [4]. Програми озброєння (довгострокові плани) координують і об'єднують зусилля для дося- 
гнення стратегічних (програмних) цілей розвитку ОВТ в необхідні терміни і в рамках виділених асигнувань. Існуюча в Україні концепція програмноцільового планування передбачає формування програмного комплекту ОВТ, в який включаються зразки ОВТ різних видів, типів і поколінь, що знаходяться на різних стадіях їх життєвого циклу. Головна ідея формування програмного комплекту ОВТ полягає в узгодженні життєвих циклів протягом програмного періоду як для наявного озброєння так і для ОВТ що розробляється [4].

Передбачається, що програмний комплект протягом програмного періоду буде змінюватися як за номенклатурою, так і за кількістю зразків того чи іншого виду або типу під впливом як керованих, так і некерованих факторів. Одні зразки будуть вибувати зі складу комплекту через їх моральне старіння, інші зразки будуть приходити на їх заміну і т.д. Керуючі впливи повинні бути спрямовані не тільки на регулювання ходу реалізації ЖЦ окремих зразків OBT, але і на підтримку такої спрямованості зміни програмного комплекту в цілому, при якій забезпечувалося б досягнення стратегічних (програмних) цілей розвитку ОВТ [4].

Існуюча [4-5] системно-концептуальна модель управління життєвим циклом зразка ОВТ передбачає, що об'єктом управління є життєвий цикл зразка OBТ і сам зразок ОВТ (його компонентний склад). Механізм управління життєвим циклом зразка ОВТ наведено на рис. 1.

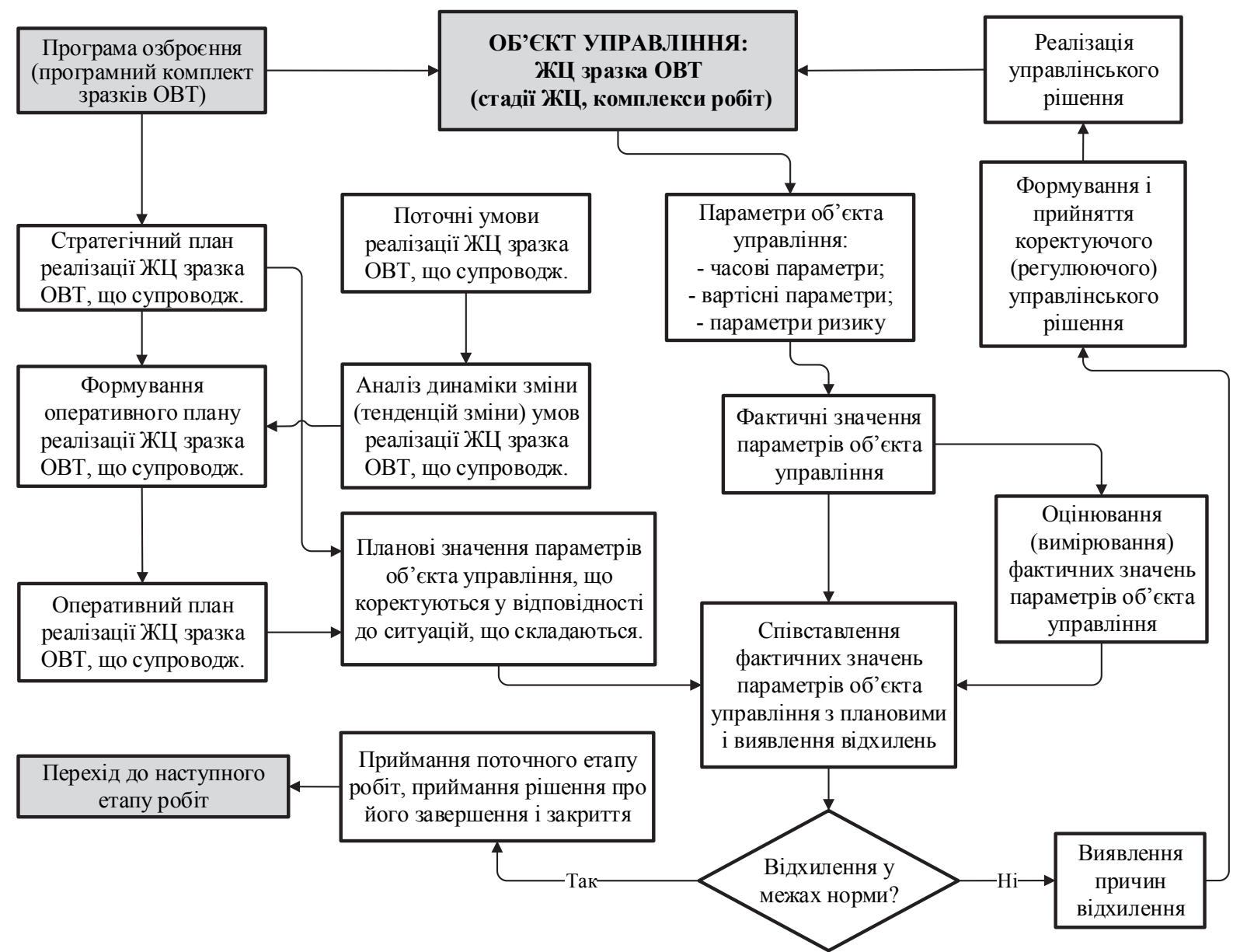

Рис. 1. Механізм управління життєвим циклом ОВТ Джерело: [4, С. 312].

Нині існує нагальна необхідність корекції даного механізму, що викликано цілим рядом причин.

Тривалість програмного періоду (10 років) менша тривалості окремих стадій ЖЦ, що робить важко реалізованим представлення управління ЖЦ ОВТ як єдиного процесу протягом всього життєвого циклу. Фактично управління ЖЦ ОВТ реалізується як механізм прийняття рішення про завершення поточного і переходу до наступного етапу робіт (рис. 1). В рамках водоспадної моделі ЖЦ такий механізм був оптимальний і активно підтримувався “військовою бюрократією” в силу того, що суб'єкт управління стоїть ніби над процесом, не втручаючись в його особливості та реалізуючи в першу чергу контрольні функції. Використання подібних механізмів при створенні ОВТ в США привело до наступних результатів. У табл. 1 наводяться дані по дослідженню 9 програм розробки ОВТ для МО США (на початок 2016 г.), які можуть розглядатися як ті, що входять до програмного комплекту ОВТ. Всі програми були 
успішні - відповідні системи були створені, але вони різняться за ефективністю проектування і фінансових витрат. У табл. 2 для програм створення i придбання ОВТ для МО США наводяться показники ресурсів-знань і схема проектування ОВТ [6].

Оцінка результатів виконання програм розробки ОВТ МО США (на початок 2016 р.)

\begin{tabular}{|c|c|c|c|c|}
\hline Програма створення ОВТ & $\begin{array}{l}\text { Початкова вар- } \\
\text { тість (млн. \$) }\end{array}$ & $\begin{array}{c}\text { Поточна оці- } \\
\text { нка (млн. \$) } \\
\end{array}$ & $\begin{array}{c}\text { Зміна } \\
\text { вартості }\end{array}$ & $\begin{array}{l}\text { Зростання часу на розробку } \\
\text { ОВТ від плану (у місяцях) }\end{array}$ \\
\hline КС-46А Програма модернізації літака-танкера & $\$ 7,149.6$ & $\$ 6,259.6$ & $-12 \%$ & 14 \\
\hline Спільний легкий тактичний транспортний засіб & $\$ 1,009.8$ & $\$ 948.9$ & $-6 \%$ & 19 \\
\hline Бомба малого діаметру, тип I & $\$ 381.3$ & $\$ 367.7$ & $-4 \%$ & -1 \\
\hline Сімейство транспортних засобів Paladin M109A7 & $\$ 1,041.7$ & $\$ 1,098.6$ & $5 \%$ & 2 \\
\hline Багатофункціональний літак P-8A Poseidon, тип I & $\$ 6,975.5$ & $\$ 7,940.4$ & $14 \%$ & 4 \\
\hline Система глобального позиціонування III & $\$ 2,512.0$ & $\$ 3,018.6$ & $20 \%$ & $\mathrm{n} / \mathrm{a}$ \\
\hline Важкий вертоліт СН-53K & $\$ 4,366.4$ & $\$ 6,598.3$ & $51 \%$ & 51 \\
\hline F-35 Lightning II & $\$ 34,400.0$ & $\$ 55,133.0$ & $60 \%$ & 62 \\
\hline Інтегрована система ППО і ПРО & $\$ 1,672.5$ & $\$ 2,632.9$ & $62 \%$ & 22 \\
\hline
\end{tabular}

Таблиця 2

Показники програм створення і придбання ОВТ для МО США

\begin{tabular}{|c|l|c|c|c|}
\hline Програма створення ОВТ & $\begin{array}{c}\text { схема проекту- } \\
\text { вання }\end{array}$ & $\begin{array}{c}\text { Рівень готовності } \\
\text { технологій }\end{array}$ & $\begin{array}{c}\text { Архітектура } \\
\text { системи }\end{array}$ & взаєодії \\
\hline КС-46А Програма модернізації літака-танкера & інкрементальна & майже зрілий & похідна & обмежена \\
\hline Спільний легкий тактичний транспортний засіб & інкрементальна & майже зрілий & похідна & обмежена \\
\hline Бомба малого діаметру, тип I & інкрементальна & зрілий & похідна & обмежена \\
\hline Сімейство транспортних засобів Рaladin M109А7 & інкрементальна & зрілий & похідна & обмежена \\
\hline Багатофункціональний літак Р-8А Роseidon, тип I & інкрементальна & незрілий & похідна & обмежена \\
\hline Система глобального позиціонування III & інкрементальна & зрілий & похідна & значна \\
\hline Важкий вертоліт СН-53К & одно-крокова & незрілий & нова & обмежена \\
\hline F-35 Lіghtпіп II & одно- крокова & незрілий & нова & значна \\
\hline Інтегрована система ППО і ПРО & інкрементальна & майже зрілий & нова & значна \\
\hline
\end{tabular}

Відповідно до думки американських фахівців перші 3 програми, наведені в табл. 1, 2 можна вважати, як правильно організовані і успішні, наступні 3 - задовільні, останні 3 - незадовільні в організаційному та фінансовому плані.

Автори доповіді [6], представленої в конгрес США вважають, що використання механізмів управління аналогічних наведеним на рис. 1, забезпечує задовільні результати при створенні порівняно простих систем ОВТ, але вкрай погано працює при управлінні ЖЦ складних систем-систем. Викликано це тим, що відрізками часу (стадіями) неможливо управляти. Коли кажуть “управління життєвим циклом” якраз говорять про управління діяльністю (а не контроль результатів діяльності) що забезпечує оптимізацію процесів, що лежать в основі стадій життєвого циклу.

Згідно сучасних підходів управління життєвим циклом систем регламентується міжнародним стандартом ISO/IEC/IEEE 15288:2015 Systems engineering. System life cycle processes (Системна інженерія. Процеси життєвого циклу системи) [7].

Життєвий цикл системи (system life cycle) - це діяльність всіх систем забезпечення, що ведуть цільову систему від іiї задуму до виведення з експлуатації (рис. 2). Слід відзначити, що в сучасній редакції стандарту 15288 фактично просувається думка про необхідність настройки і адаптації - тейлорингу (tailoring) життєвого циклу системи як в рамках деякого проекту, так і окремого підприємства, що бере участь у проекті.

3 огляду на те, що в рамках сучасного уявлення про життєвий цикл ЗРС [1] окремі стадії ЖЦ можуть за часом накладатися одна на одну, це призводить до паралельного існування різних систем забезпечення ЖЦ ЗРС. Таким чином виникає необхідність створення інтегрованих екосистем забезпечення ЖЦ ЗРС і зміни об'єкту керування.

Архітектура екосистеми ЗРС, а не сам зразок OBТ та його життєвий цикл, починають виступати у якості об'єкту керування. Екосистема ЗРС, що будується на засадах соціокультурних моделей побудови організацій і мультирозумних систем істотно відрізняється від класичних складних систем і має всі риси дата-центричної системи-систем. Коротко зупинимося на цих відмінностях. 


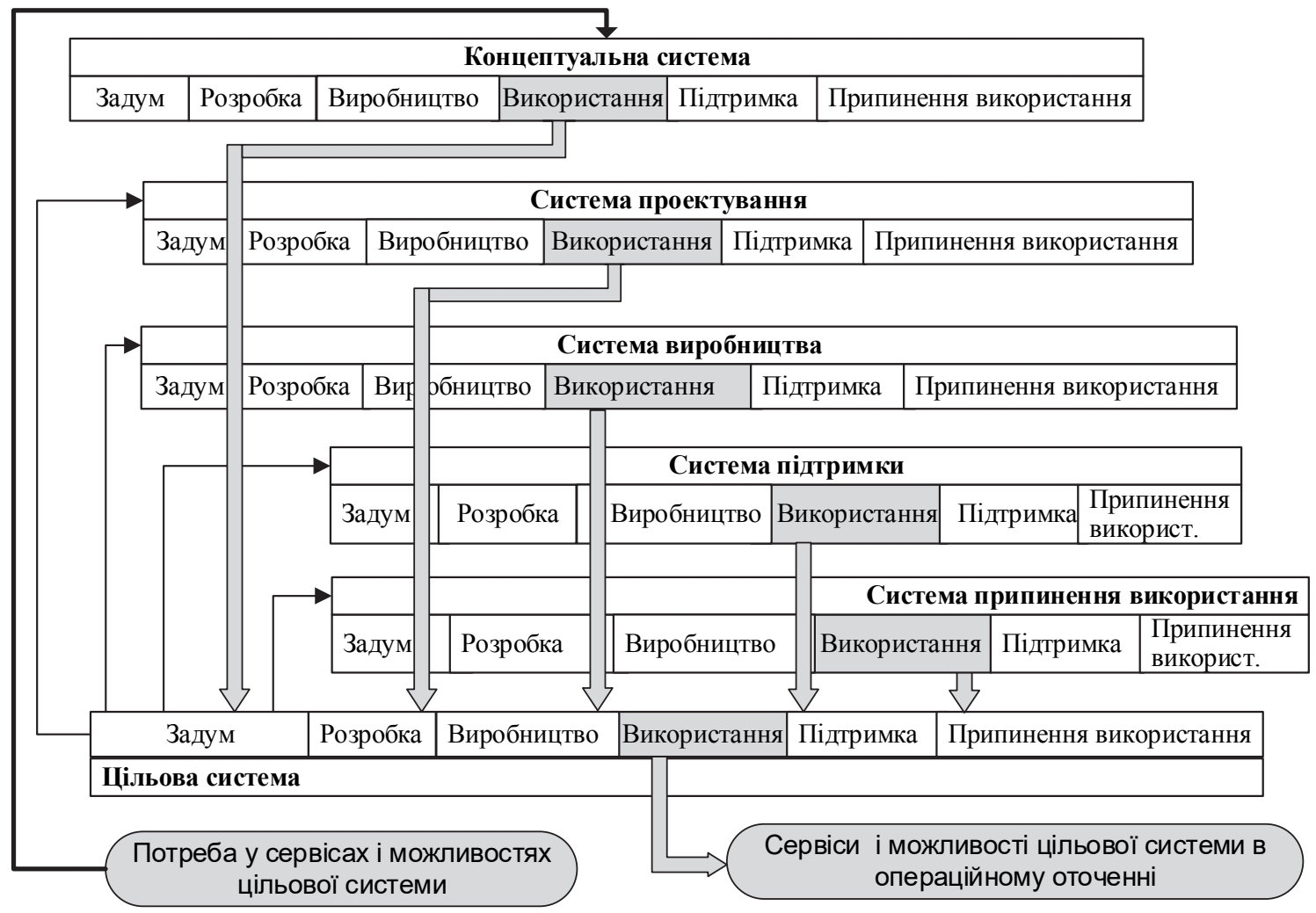

Рис. 2. Процеси життєвого циклу ISO/IEC/IEEE 15288

Джерело: розроблено автором за даними [7].

В рамках “класичного” системного мислення для опису системи використовується структурний підхід (системи розбиваються на підсистеми й елементи) і функціональний підхід, в рамках якого використовується модель: функції - зв'язки - об'єкти (ФЗО). Модель ФЗО будується 3 використанням теорії графів. Об'єкти, розташовані в вершинах графів, інкапсулюють функції, а зв'язність об'єктів представляється дугами графів. При цьому візуально структуру системи можна уявити, як тривимірну складну кристалічну решітку (найбільш близький візуальний аналог - кристалічна решітка алмаза), в якій кульки (об'єкти) з'єднуються між собою дротинками (зв'язки). Додаючи або прибираючи відповідні “ дротинки” і “кульки” можна розглядати структурну мінливість або деградацію систем (рис. 3).

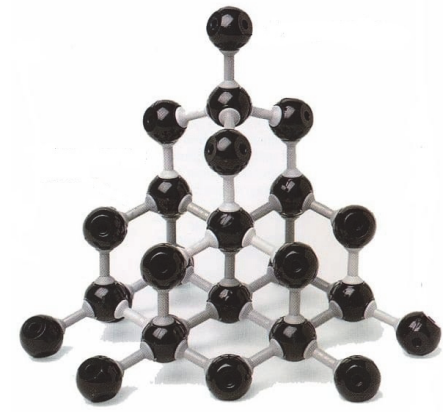

Рис. 3. Загальна структура ФЗО моделі системи Джерело: розроблено автором.
Розвиток мереж призвів до виникнення фізичної та логічної топології. Фізична топологія - це структура зв'язку фізичних пристроїв в мережі. Логічна топологія - це яким шляхом будуть йти пакети даних у фізичній топології. В рамках цих двох топологій виділяються сім рівнів (модель ISO - International Organization for Standardization):

1) фізичний рівень (physical layer);

2) канальний рівень (data link layer);

3) мережевий рівень (network layer);

4) транспортний рівень (transport layer;

5) сеансовий рівень (session layer);

6) рівень представлення (presentation layer), або інакше структурування інформації;

7) прикладний рівень (application layer) - рівень роботи сервісів та додатків.

3 наукової точки зору використання мережеємних систем призвело до цікавих результатів.

Фізична топологія мережі ЗРС, як правило, містить мало інформації про функціональну організацію мереже-ємної системи (рис. 4). Системи на кожному з рівнів “знають”, тільки про існування верхнього і нижнього рівнів, які для них стають “середовищем”. Кожен рівень відділений від іншого рівня якимось інтерфейсом. Реалізації нижчих рівнів тим самим можуть бути змінені так, що цільова система цього не помітить. Таке представлення зв'язків призводить до того, що звична візуалізація структури 
системи розсипається, часто об'єкти не взаємодіють, але при цьому взаємозалежні (що і призвело до появи більш абстрактного поняття - архітектура).

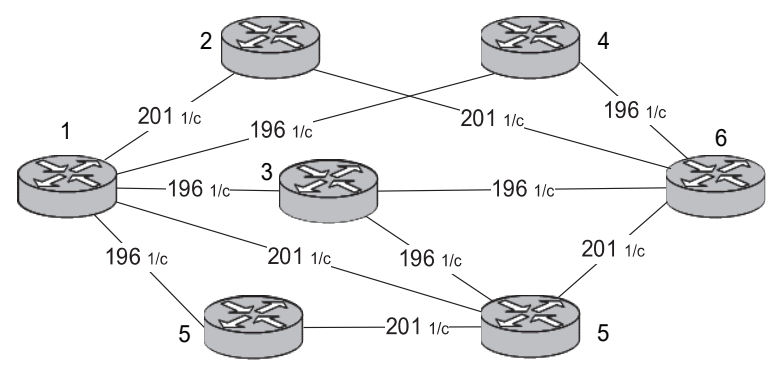

Рис. 4. Фізична топологія мережі ЗРС Джерело: розроблено автором.

Слід також зазначити, що сучасне розуміння мережеємних систем, що складаються з систем (system of systems, SoS) призвело до вибухового зростання цифрових, технологічних, бізнес і стартап екосистем [8].

У біологічному плані екосистема визначається як функціональна єдність живих організмів і середовища їх проживання. Цифрові і технологічні екосистеми є SoS, що об'єднуються навколо деякої платформи, сервісу або цільової системи. Прикладами екосистем, створюваних навколо певної цифрової платформи є екосистеми Google, Amazon, Facebook. Прикладом екосистем, створюваних навколо сервісу може служити екосистема глобальної навігаційної системи GPS.

Відзначимо, що екосистеми, створювані навколо деякої цільової системи або навіть вдалого технологічного рішення, можуть і не мати бренду, що їх об'єднує. Прикладом може служити екосистема, що склалася навколо автомата Калашникова. Вдале технічне рішення зумовило появу всіляких клонів цієї зброї. Використання планок Пікатинні, різних варіантів прицілів, глушників, магазинів, патронів, тактичних ліхтариків і т.д., забезпечило можливість індивідуальної адаптації автомата користувачами під власні потреби. Все це обладнання розробляється і виробляється десятками і сотнями різних фірм.

Фактично, екосистема - це мережа міжгалузевих гравців, які працюють разом над визначенням, створенням і реалізацією ринкових рішень для клієнтів і споживачів.

Архітектура перспективної ЗРС, що розробляється як дата-центрична система, передбачає зміщення акцентів від модульності побудови системи в бік сервіс-орієнтованої архітектури та використання хмарних технологій. Відмова від прив'язки ЗРС до певної транспортної платформи з одночасним використанням стандарту NATO AEP-4754 “Загальна архітектура транспортних засобів NATO для наземних систем" [9] і введення до складу ЗРС засобів розширення бойових спроможностей дозволить створити найширші умови для розробки морських, автомобільних, гусеничних модифікацій ЗРС, експортних варіантів виконання, адаптуються під взаємодію з національними системами ППО різних країн, забезпечить введення до складу ЗРС систем і устаткування сторонніх виробників. Все це приводить нас до того, що архітектура побудови ЗРС повинна з самого початку розглядатися як технологічне ядро для створення екосистеми ЗРС.

В першу чергу слід відзначити вплив архітектури створюваної системи ЗРС на процес проектування. Якщо система створюється на базі існуючої архітектури (є похідною від неї), то ризики значно нижче. Однак принципово нові системи, як правило, створити в рамках існуючої архітектури неможливо. Але ще більш важливе те, що ЗРС, що має принципово нову архітектуру створити у рамках існуючих проектних організацій дуже складно. І тут необхідно привести зауваження відомого системного аналітика J. Gharajedaghi: "Парадоксально, але ймовірність неадекватної реакції організації на ключові науковотехнічні відкриття прямо пропорційна ступеню успіху, досягнутого через застосування провідною до цього моменту технології. Іншими словами, чим більшого процвітання досягає компанія завдяки певній технології, тим вище іiі опір будь-яким змінам" [10]. Це призводить до того, що створення нових систем ОВТ здійснюється в рамках однієї відпрацьованої концепції лише шляхом нарощування функціональних можливостей. Прикладом реалізації такого підходу є створення лінійки ЗРС: С-300П, С300ПМУ-1, С-300ПМУ-2, С-400. Вже близько п'ятдесяти років розробляються системи на базі однієї концепції (технічного рішення). I навпаки, створюване Ілоном Маском підприємство, яке немає “тягарю успадкування" у короткий час розробило принципово нову ракету-носій, що кардинально змінило ринок космічних перевезень.

Таким чином, екосистема ЗРС повинна забезпечувати відповідність архітектури системи підтримки життєвого циклу створюваній архітектурі перспективної ЗРС (рис. 5). Формування архітектури екосистеми ЗРС має здійснюватися на базі процесного представлення ЖЦ.

Перехід до процесного представлення ЖЦ кардинально змінює всю суть управління роботами над цільовою системою (створенням ЗРС).

Класичний механізм управління (рис. 1) фактично передбачає поділ робіт протягом усього життєвого циклу на два основні типи: виробничий акт i координаційні акти. 


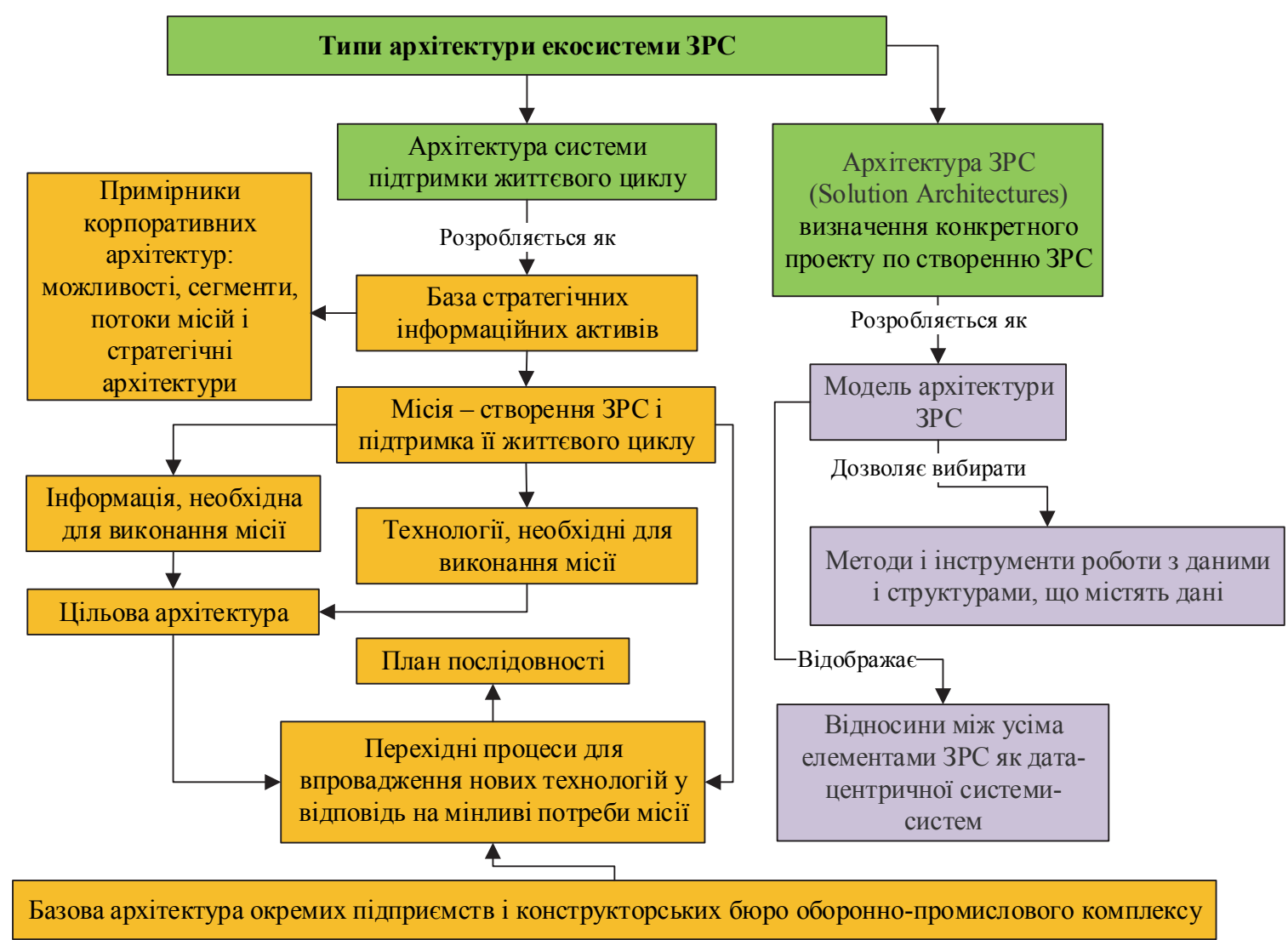

Рис. 5. Архітектура екосистеми ЗРС

Джерело: розроблено автором.

Виробничий акт - реальне виконання робіт. Координаційний акт - мова йде про інформаційний світ доручень-узгоджень, але не про реальну роботу по зміні світу. Ухвалення роботи до виконання, пред'явлення виконаних робіт, прийняття виконаних робіт все це координаційні акти. Розподіл на координаційні та виробничі акти важливий, щоб робити правильні оцінки часу. Від моменту затребування роботи до моменту прийняття роботи на координаційні акти може йти до $40 \%$ часу і тільки $60 \%$ часу на проведення самої роботи. Упор при цьому робиться фактично на тому: коли і ким буде виконуватися робота, коли вона буде закінчена [11-12].

Перехід до процесів (практик) - це перехід до обговорення в першу чергу функціонального аспекту робіт і тільки потім до їх виконавців. Життевий цикл представляється як послідовність виконання стандартизованих практик [7]. Це дозволяє чітко формулювати вимоги до організацій, що здійснюють ті чи інші роботи на поточному етапі функціонування екосистеми ЗРС. Організація взаємодії окремих підприємств в рамках життєвого циклу повинна здійснюватися відповідно до процесів (практик), визначених в ISO / IEC / IEEE 15288 (рис. 6).

В рамках використання програмного комплекту ОВТ та водоспадної моделі ЖЦ вибір можливих дій по досягненню стратегічних (програмних) цілей розвитку ОВТ вкрай обмежений. Саме тому, в США відбувається зміна загальної стратегії розробки і придбання озброєння - приймається "Weapons Systems Acquisition Reform Act”, який як один з основних інструментів розглядає спільну систему інтеграції і розвитку можливостей (JCIDS) [13]. Система JCIDS в першу чергу розглядає питання придбання бойових можливостей ЗС США, однак на наш погляд даний підхід може бути розширений не тільки на цільові системи, але і на визначення можливостей, які на різних фазах життєвого циклу повинна мати екосистема ЗРС. На рис. 7 приведена модель архітектури системи інтеграції і розвитку можливостей по створенню екосистеми ЗРС. Дана модель передбачає наступне. Спочатку необхідно прописати процеси ЖЦ екосистеми ЗРС як складові інтегрованого загального процесу розвитку можливостей збройних сил. На відміну від програм розвитку озброєнь (які тепер виступають як складова частина моделі) загальний процес розглядає значно більшу кількість факторів, що впливають на придбання необхідних можливостей, які відповідно до підходів, прийнятими в країнах блоку NATO групуються в відповідні домени. Однак слід враховувати, що процеси ЖЦ пишуться виключно на підставі вихідних даних, збір і систематизація яких $€$ окремим завданням. 


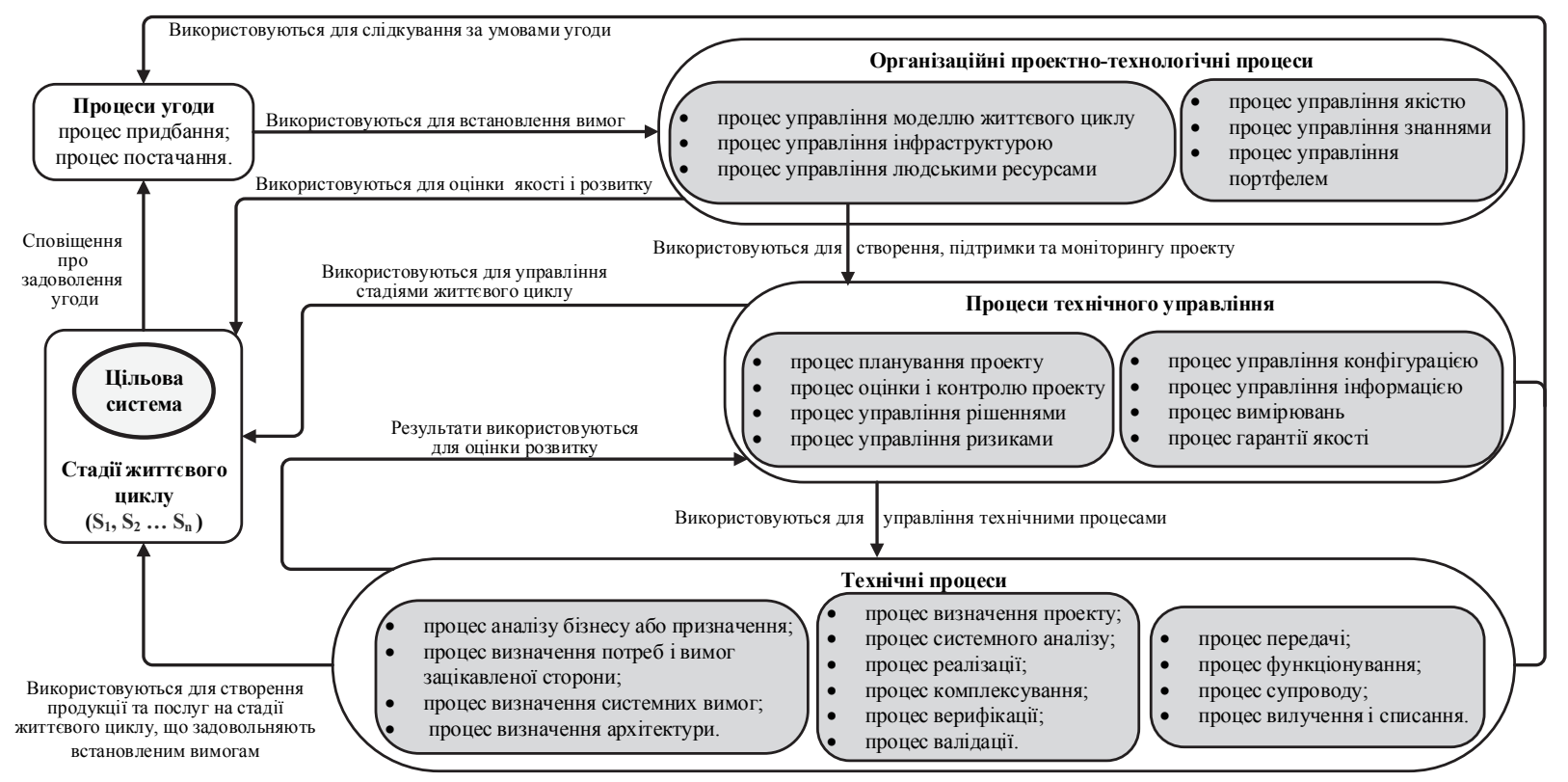

Рис. 6. Процеси життєвого циклу ISO/IEC/IEEE 15288

Джерело: розроблено автором за даними [7].

Далі здійснюється систематизація процесів, розподіл їх уздовж лінії ЖЦ ЗРС формованої у вигляді моделі Ганта. Варіант побудова діаграмі моделі життєвого циклу перспективної ЗРС приведено у роботі [1]. Удосконалення процесів здійснюється в продовж всього життєвого циклу ЗРС. Розробка моделей архітектури передбачає в першу чергу формування системи показників / критеріїв. Всі дії повинні бути вимірні.

Вибір методології моделювання в першу чергу визначається способами роботи зі структурами, що містять дані, тобто архітектурними фреймворками (AF). Передбачається, що в рамках робіт зі створення перспективної ЗРС буде розроблено вітчизняний спеціалізований архітектурний фреймворк AFADS (Architecture framework Air Defense System), який забезпечить формування єдиних підходів до створення архітектури перспективної дата-центричної ЗРC і уніфікацію зі AF країн NATO. Приведемо визначення AFADS дане в роботі [14]: “угоди, принципи і практики, які стосуються діяльності по створенню архітектури зенітної ракетної системи і екосистеми ЗРС".

При розробці методології створення архітектури дата-центричної екосистеми ЗРС необхідно враховувати вимоги щодо гармонізації процесів створення ЗРС зі стандартами NATO. Виходячи з цього доцільно використовувати загальну модель структури управління життєвим циклом ОВТ, приведену на рис. 8. Загальна структура методу створення архітектури екосистеми ЗРС приведена на рис. 9.

Як дата-центрична система-систем, екосистема ЗРС реалізує парадигму: “взаємозалежність, самоорганізація і вибір” [2; 14].
Ускладнення процесів проектування перспективної ЗРС призвело до поглиблення спеціалізації розробників тобто їх диференціації, а встановлення міждисциплінарних зв'язків в рамках створення екосистеми ЗРС породжує процеси інтеграції, при цьому виникають чотири рівні взаємозалежності: 1) організація (Organization); 2) сфера діяльності / наукова дисципліна (Discipline); 3) люди з їх компетенціями; 4) дані.

Самоорганізація екосистеми ЗРС полягає в узгодженні об'єктів на всіх чотирьох рівнях взаємозалежності, що забезпечує цілеспрямовану поведінку системи. Людина, завдяки організації отримує доступ до інструментів, технологій (організація від грец. 'О $\gamma \alpha v o v$ - інструмент) і даних, реалізуючи при цьому цілеспрямовану поведінку у відповідності зі своїми компетенціями в деякій сфері діяльності.

При цьому люди в рамках кожної фази життевого циклу екосистеми повинні спрацювати по якомусь організаційного алгоритму реалізувавши певний робочий процес - workflow. Такий робочий процес найбільш зручно представити в 4D-просторі, положення в якому (екстент) являє собою місцефункцію. У точці екстенту об'єднуються необхідні для вирішення деякої задачі об'єкти всіх рівнів взаємозалежності. Об'єднання відбувається тільки в часі, просторово об'єкти можуть різнитися. За своїми властивостями об'єкти поділяються на дві основні групи (стандарт ISO 15926): функціональні (абстрактні) і фізичні.

Наявність фізичних і абстрактних об'єктів, просторової і часової їх локалізації роблять актуальним використання багатошарової метамоделі представлення процесів і моделей дата-центричної операції 
(рис. 10) в рамках якої відбувається створення екосистеми ЗРС.

Початковий шар (шар 0) - це 3D простір існування фізичних об'єктів (індивідів), які відображаються на всі рівні метамоделі.

Шар описових моделей - це абстрактний шар, який утворюється як відображення існуючих в реальному світі описових моделей побудови систем. Описові моделі можуть бути виконані, наприклад, в пояснювальній записці і існувати у вигляді паперових документів або на комп'ютері у вигляді файлу даних (шар 0).

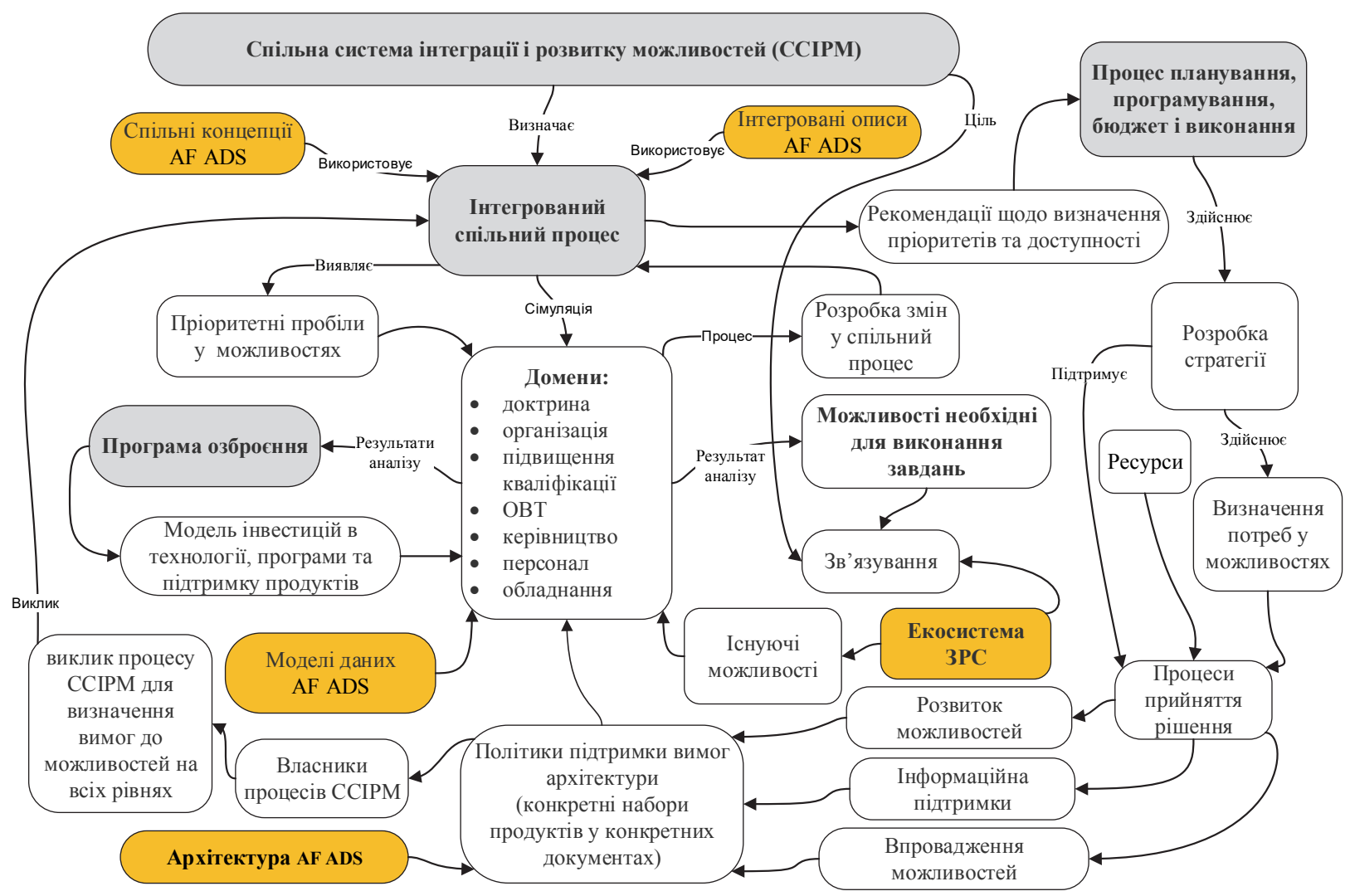

Рис. 7. Модель архітектури системи інтеграції і розвитку можливостей по створенню екосистеми ЗРС Джерело: розроблено автором.

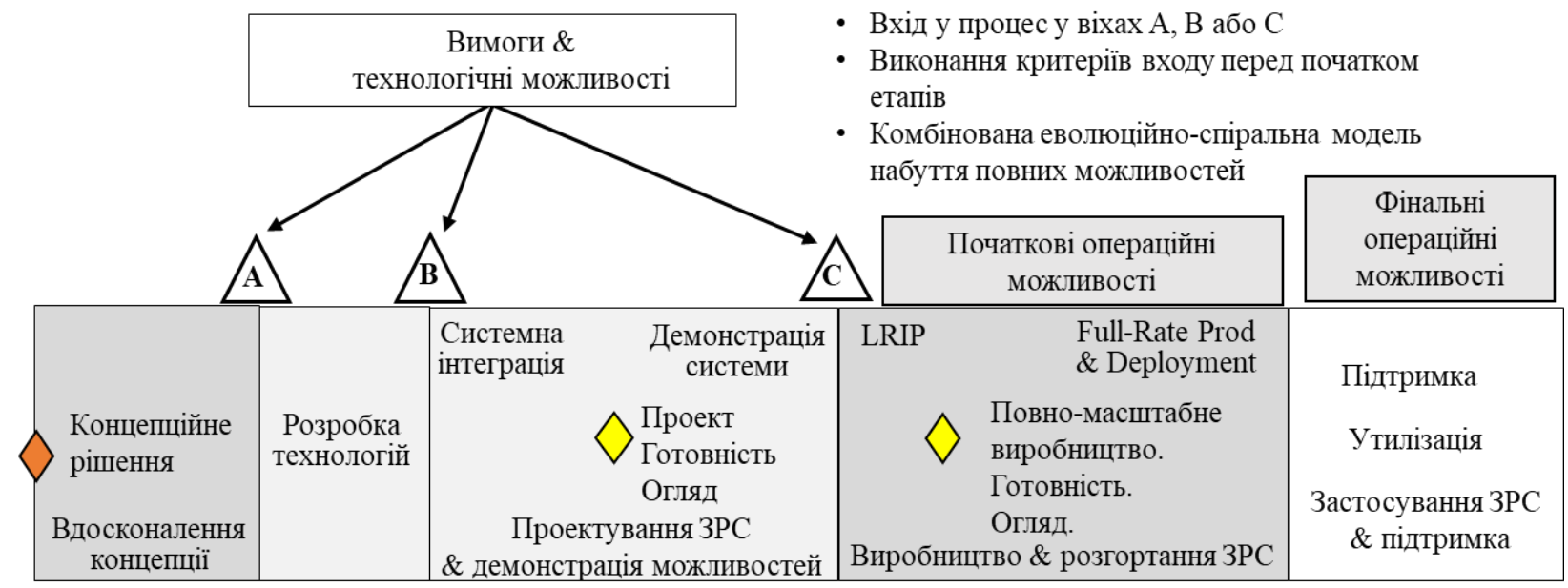
Попереднє придбання
Придбання систем систем

Початкові можливості

Підтримка

(Initial capabilities)

Розвиток можливостей

Можливість виробництва

Валідація \&

Взаємозв'язок з процесом виконаннй вимог

Рис. 8. Модель структури управління життєвим циклом ОВТ

Джерело: розроблено автором за даними [13]. 


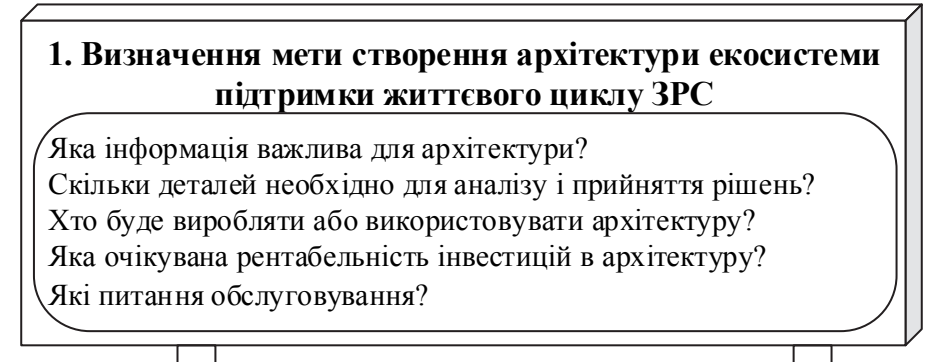

\section{2. Визначення питань діяльності екосистеми ЗРС}

визначення питань, які мають вирішальне значення для бізнесу; виділення тих питань, відповіді на які невідомі замовнику або важко формалізуються.

\section{4. Визначення базового типу} архітектурного фреймворку

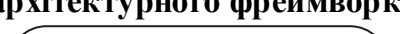

AF ADS

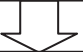

\section{3. Визначення припущень і правил} діяльності екосистеми ЗРС

Визначення правил діяльності , які обмежують або пояснюють сферу інтересів екосистеми ЗРС

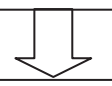

\section{5. Визначення особливостей використання фреймворка} в архітектурі екосистеми ЗРC

фреймворк надає вказівки щодо того, що моделювати (допомогає з вибором методологіі);

методологія надає вказівки щодо того, як моделювати.

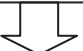

\section{6. Створення метамоделі екосистеми підтримки життєвого циклу ЗРС}

Метамодель - це абстрактний вид архітектури. Вона показує використовувані дані і відносини між даними. Зв'язуються тільки ті сутності, які мають логічні відносини.

Метамодель повинна включати в себе наступні функції:

- визначення елементів;

- відносини між елементами архітектури;

- простежуваність до ділових питань.

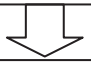

\section{7. Визначення моделей, необхідних в архітектурі екосистеми ЗРС}

Метамодель - це абстрактний вид архітектури. Вона показує використовувані дані і відносини між даними. Зв'язуються тільки ті сутності, які мають логічні відносини.

Метамодель повинна включати в себе наступні функції:

- визначення елементів;

- відносини між елементами архітектури;

- простежуваність до ділових питань.

\section{8. Інтеграція архітектури еко-системи}

Зв'язування зібраних даних на основі виявлених відносин.

Аналіз архітектури: кількісний аналіз може використовуватися для виявлення вузьких місць в практиках, економії часу, економії витрат і усунення надмірності; якісний аналіз виконується шляхом перегляду моделі, 3 метою виявлення потенційних проблем.

Рішення адміністративних питань:

як і де буде розгорнуто корпоративна архітектура;

склад команди;

визначення рівнів доступу та використання інформації; визначення переліку стандартів.

Рис. 9. Загальна структура методу створення архітектури екосистеми ЗРС Джерело: розроблено автором.

Вони можуть представляти собою, як чисто текстовий опис принципу дії системи, так і різні мате- матичні моделі та алгоритми. Наступний шар - шар екстентів (моделі предметної області) визначає міс- 
це індивіда в 4D просторі. Це шар проекцій реально існуючих систем і предметних (втілених) моделей на деякий загальний для них екстент.

За своєю суттю екстент - це місце-функція. Поняття шару екстентів декілька контрінтуїтивне, воно виходить 3 того, що опис математичної або іншої моделі системи це не є сама система. Саме тому в системній інженерії розділяють поняття: опис системи, визначення системи і втілення системи. Слово “втілення” (realization) означає буквально: “переклад в реальність”. І тут ми приходимо до ще однієї важливої речі - до диференціації форм представлення знань і диференції ступенів розуміння знань. Людина, що володіє відповідними знаннями, читаючи звіт про науково-дослідну роботу може в своєму мозку (подібно до комп'ютера) уречевлювати систему на основі їі опису. Тобто предметна модель - це описова модель системи (операції) запущена для виконання на комп'ютері або матеріалізована в мозку людини і представляє собою одну 3 форм втілення системи.

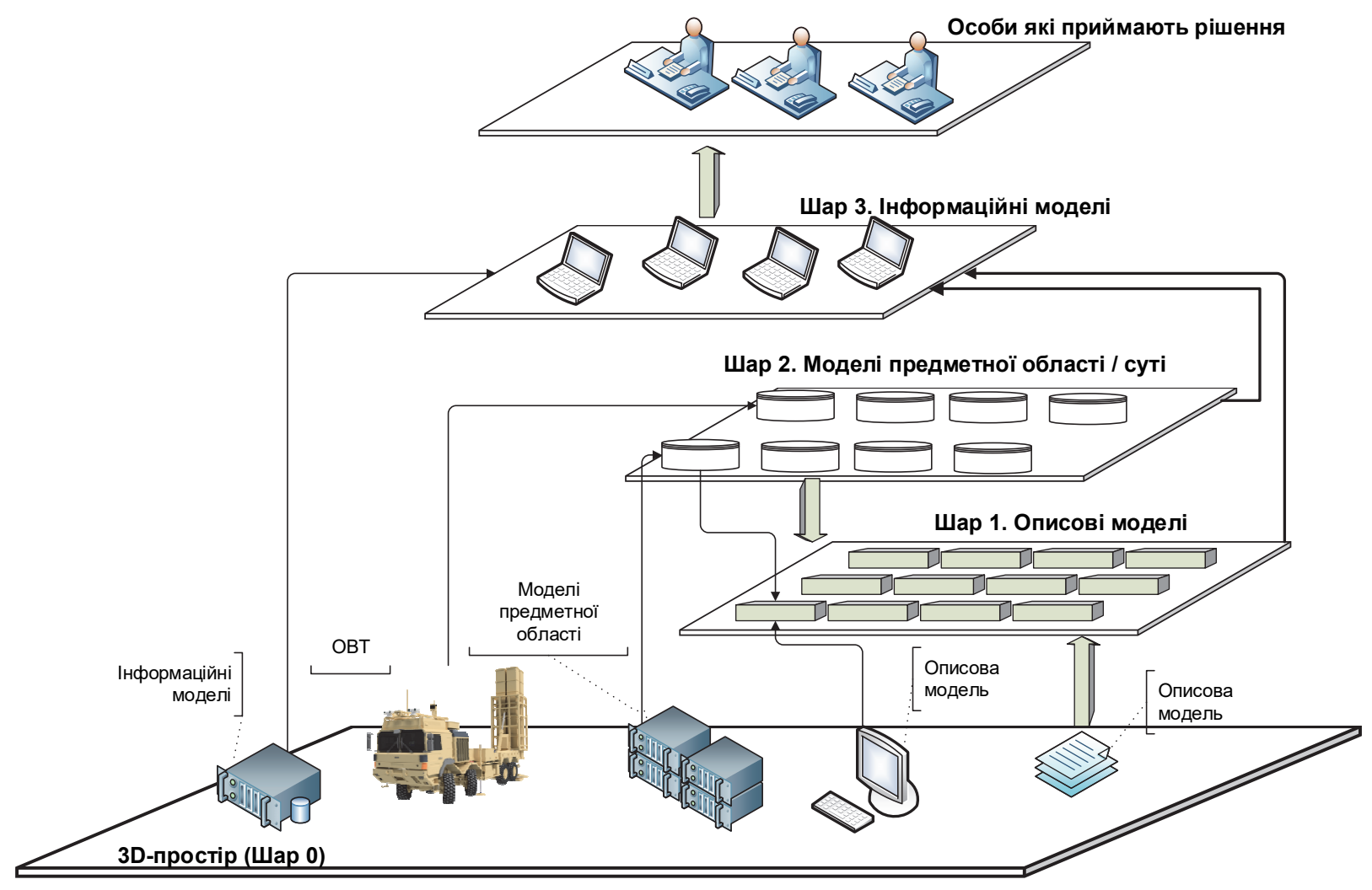

Рис. 10. Метамодель дата-центричної операції по створення екосистеми ЗРС Джерело: розроблено автором.

На різних часових перетинах екстенту предметна модель змінюється і в кінцевому підсумку замінюється проекцією реальної системи на цей екстент. При цьому, вже описові моделі підлягають корекції для відповідності реально існуючій системі-систем.

Складність систем-систем дуже звузило можливості людини по уявному втіленню SoS. Тому завдання формування цілісного розуміння системи у осіб що приймають рішення (ОПР) набула особливої актуальності. Для реалізації такої можливості створюється шар інформаційних моделей, що представляють собою спрощені моделі знання про операцію (систему), що формуються відповідно до компетенцій ОПР. Одна людина, навіть якщо вона геній, не в змозі утримати цілісність. Цілісність утримується в сучасному світі лише командно, що знову приводить нас до питань “організації”.
Важливо відзначити, що проектні та інші організації, що входять до складу екосистеми ЗРС в своєму розвитку повинні враховувати розвиток соціуму. Розвиток соціуму призвів до того, що людство відкидає патерналістську культуру. Людина формує культуру, але й культура формує людину. I якщо раніше була дуже важлива роль авторитетів, успіхи створення складних систем багато в чому зв'язувалися 3 геніальністю іх генеральних конструкторів, то тепер в екосистемі значно зростає роль міждисциплінарних зв'язків, завдяки яким продукується нове знання.

Надзвичайне ускладнення проектованих систем призвело до вузької спеціалізації інженерів. На рис. 11 представлена умовна модель рівнів індивідуальної компетенції (знань / досвіду) інженерів і компетенції команди розробників в міждисципліна- 
рній групі. Модель виконана у вигляді тривимірної структури, де по одній осі розташовані рівень компетенції, а по двох інших областях наявних знань (мо- делі знань) і досвід (моделі-поведінки, шаблони дій, володіння певними технологіями і інструментами).
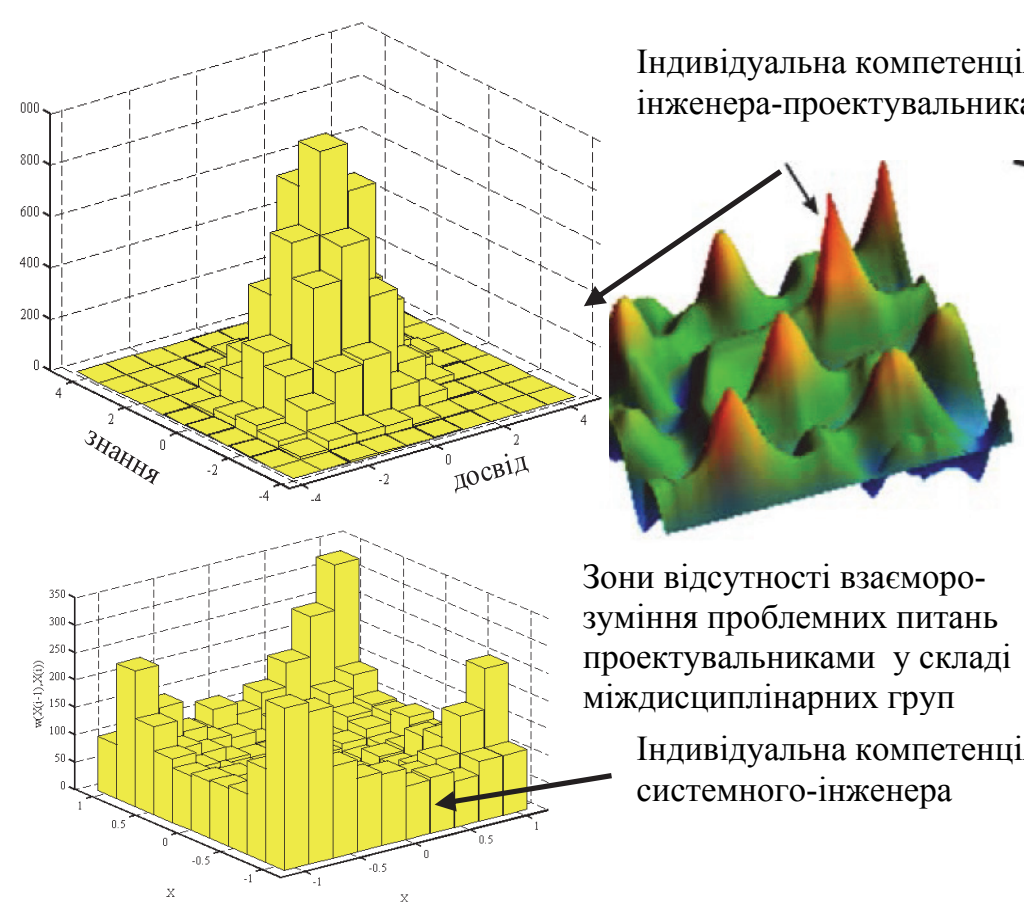

Зони відсутності взаєморозуміння проблемних питань проектувальниками у складі міждисциплінарних груп

Індивідуальна компетенція системного-інженера

Рис. 11. Модель командної компетенції міждисциплінарної групи та індивідуальні компетенції (рівнів знань/досвіду) фахівців Джерело: розроблено автором.

Міждисциплінарна взаємодія окремих фахівців ускладняється в силу не перетинання областей їх компетенцій. На рис. 11, цій проблематиці відповідають зони відсутності взаєморозуміння проблемних питань проектувальниками у складі міждисциплінарних груп.

Горизонтальні зв'язки між проектувальниками різних команд стають неможливими, що вимагає створення між ними “прошарку” - міждисциплінарних системно-інженерних структур. Роль системних інженерів в першу чергу полягає в формуванні цілісності сприйняття системи усіма членами команди. Для випадку створення перспективної ЗРС системний інженер (рис. 11) має максимальні (пікові) значення компетенцій в областях бойового застосування (тактики) ЗРС і побудови озброєння ЗРС, зона між якими відповідає широкому колу технічних дисциплін, визначаючих особливості технічної реалізації систем ОВТ.

Разом з тим, слід зазначити, що саме по собі включення до складу міждисциплінарних груп системних інженерів не усуває проблему взаємодії на рівні горизонтальних зв'язків. Одна з основних задач системи управління у рамках екосистеми ЗРС - це запобігання конфігураційних колізій [1]. Колізії - це протиріччя (невідповідності) одних частин проектованої ЗРС іншим.

Протиріччя неминуче з'являються при ко- лаборативній розробці перспективної ЗРС. Різні учасники проектування ЗРС діють в ситуації неповної інформації як про ЗРС - як цільову систему в іiі поточному (або прогнозованому далі по життєвому циклу) стані, так і про дії та цілі один одного. Крім того, впродовж “руху” ЗРС по життєвому циклу неминуче виникнуть додаткові колізії між ЗРС і системами в іiі операційному оточенні. Чим пізніше по життєвому циклу буде виявлена колізія, тим дорожче іiі виправлення. Для боротьби з колізіями процеси створення ЗРС мають носити рекурсивний характер і відповідати вимогам стандарту IEEE-1220 (рис. 12) [15].

Наступний важливий фактор, що пов'язаний 3 управлінням екосистеми ЗРС є управління ризиками. Найбільш перспективний напрямок управління ризиками базується на підході, заснованому на знаннях [11-12].

Високий рівень знань про ті чи інші особливості ЗРС необхідний в ключових точках життєвого циклу. Вважається, що рівень ризику мінімальний, якщо досягається відповідність між потребами або вимогами замовника і доступними ресурсами системи проектування (знання відносяться до нематеріальних ресурсів), до головних з яких можна віднести знання архітектури перспективної ЗРС, технологічні напрацювання або інакше - рівень готовності технологій (TRL - technology readiness level), ступінь інтеграції та взаємодії проектованої ЗРС 3 
системами операційного оточення і необхідне фінансування (див. табл. 2).

Рівень готовності технологій показує ступінь зрілості критичних технологій для системи ОВТ на початку їі розробки. Критичні технології оцінюються за шкалою від 1 до 9, причому 9 є найбільш зрі- лою (рис. 13) [16]. Демонстрація технології у відповідному середовищі - 6 TRL, демонстрація в операційному середовищі - 7 TRL. Демонстрація технологій в операційному середовищі забезпечує більш високий рівень розуміння технології і знижує ризики до початку розробки ОВТ.

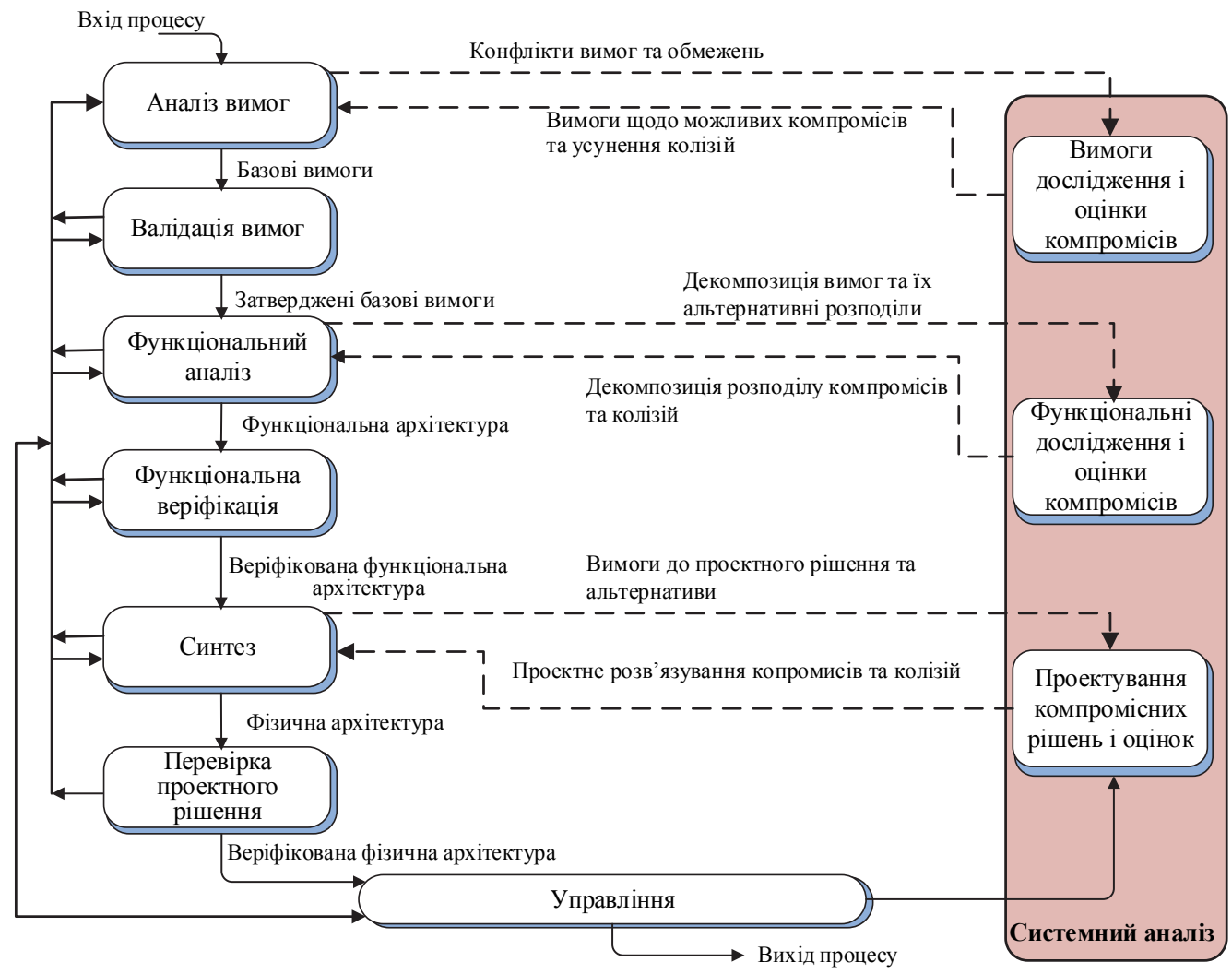

Рис. 12. Рекурсивне представлення процесів створення ЗРС Джерело: розроблено автором за даними [15].

Початок розробки системи 3 використанням менш зрілих технологій (TRL нижче 7) збільшує ризик, оскільки непередбачені технологічні проблеми можуть істотно вплинути на архітектуру проектованої системи [17]. В 2013 году шкала TRL була прийнята в якості стандарту ISO 16290: 2013 (рис. 11).

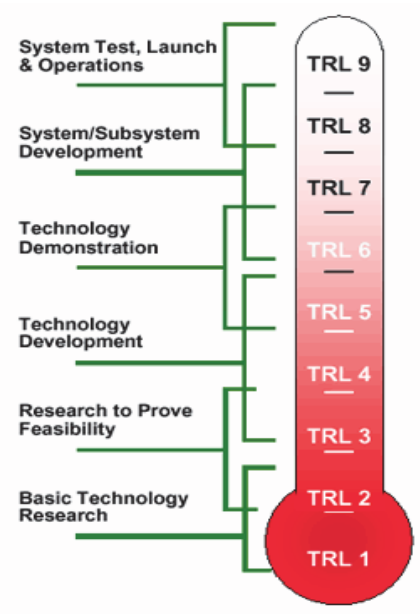

Рис. 13. Рівні технологічної готовності. Джерело: [16]
Виходячи з рівня готовності технологій визначається часова схема створення ЗРС [1]:

- one step design model - одно-крокова модель проектування ЗРС;

- evolutionary incremental design model багатокрокова еволюційна інкрементна модель проектування;

- evolutionary spiral design model - багатокрокова еволюційна спіральна модель;

- accelerated acquisition program - програма прискореного придбання.

Еволюційний підхід до проектування здійснюється 3 використанням інкрементної або спіральної схеми розвитку [18]. Особливості використання еволюційних схем приведені на рис. 14 .

Повертаючись до показників, приведених у табл. 2 ми можемо зробити висновок про переважаюче використання інкрементної схеми розвитку. Програми створення вертольоту СН-53K і винищувача F-35 імовірно спочатку розглядалися як програми прискореного придбання, що і призвело до суттєвих труднощів виконання цих програм. Для цілей нашого аналізу найбільш цікавою є програма 
розробки інтегрованої системи ППО і ПРО (IAMD

- Integrated Air and Missile Defense).

Не дивлячись на те, що генеральний підрядник IAMD спільно з армійськими фахівцями провели на початку проектування системи детальну розробку архітектури IAMD і технології були оцінені як “майже зрілі” виявилося, що основні труднощі програми IAMD в значній мірі визначаються питаннями спільного функціонування інформаційних систем систем зброї, які розроблялися як окремі програми. Системна взаємозалежність в програмі IAMD призвела до того, що вже на 1-му році розробки пред- ставники армії внесли суттєві зміни в обрис інтегрованої системи ППО и ПРО, в результаті чого до складу IAMD стало потрібним інтегрувати додаткові системи і провести дослідження з питань взаємодії. За словами офіційних осіб головного підрядника, три з чотирьох критично важливих технологій IAMD засновані на взаємодії з іншими системами. Розробники зіткнулися також з проблемами інтеграції нового програмного забезпечення $з$ програмними засобами систем операційного оточення, критично важливими для функціонування IAMD.

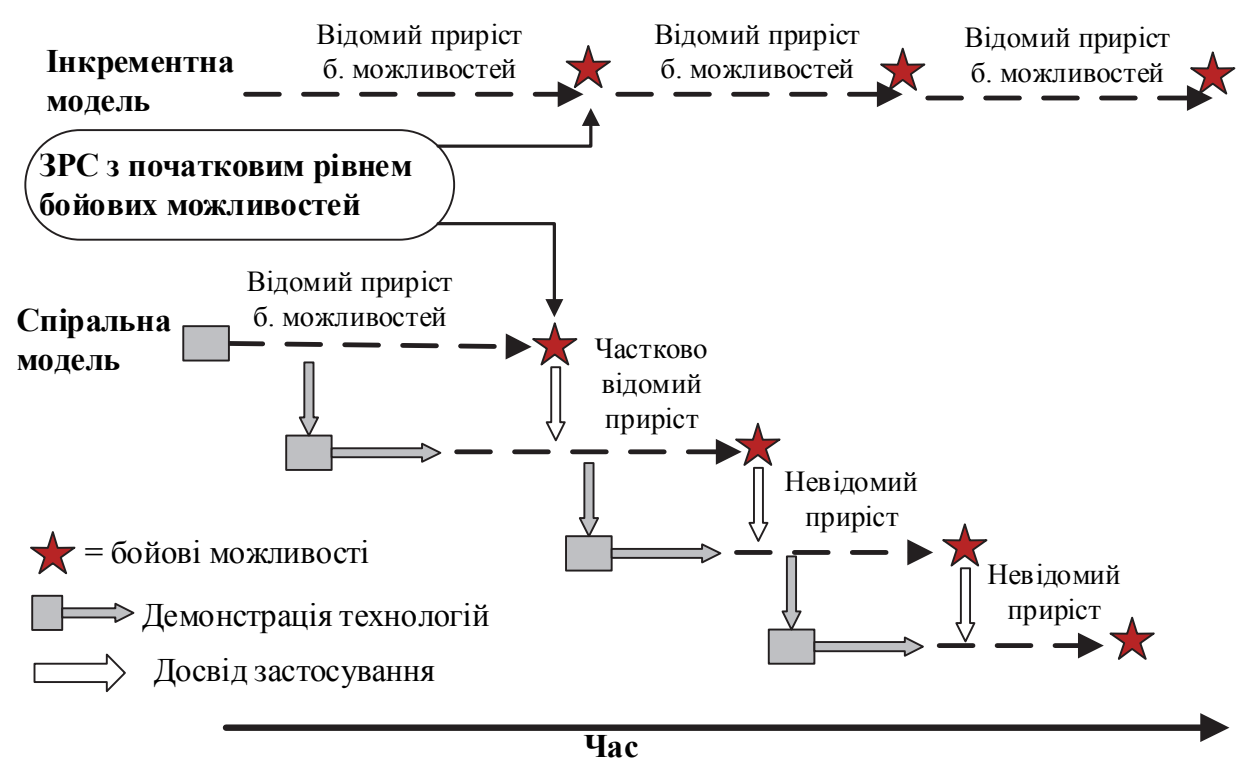

Рис. 14. Еволюційна схема проектування: інкрементний і спіральний розвиток Джерело: розроблено автором за даними [18].

Таким чином можна констатувати, що при розробці систем ППО и ПРО, які використовують нову архітектуру i функціонують в умовах підвищеної взаємодії з системами операційного оточення, в силу неможливості до початку проектування повністю сформулювати вимоги щодо систем-систем, найкращим є комбінація інкрементної і спіральної моделей еволюційного проектування.

Шанси успішного створення такої складної системи як ЗРС наступного покоління будуть максимальними, якщо процес розробки здійснюється в серії невеликих кроків для кожного з яких визначається частково відомий приріст бойових можливостей. Тобто за основу приймається інкрементна модель. Кожен крок містить в собі певний успіх, заснований на впровадженні сукупності зрілих технологій. Еволюційна складова полягає у тому, що за результатами демонстрації технологій i досвіду практичного застосування прототипу ЗРС приймається рішення про корекцію вимог до бойових можливостей на наступному кроці створення ЗРС.

Комбінована еволюційно-спіральна модель створення перспективної ЗРС повинна спиратися на використання принципу “гнучкого” розвитку, який передбачає що у якості прототипу використовуються існуючі зразки ЗРС 5-го покоління, проектування здійснюється, коли більшість необхідних технологій вже $\epsilon$ на ринку, їх вартості помірні, а елементна база, що може бути застосована більш розвинена ніж та, що застосовується в існуючих ЗРС. Крім того, є можливість використання в перспективній ЗРС частини розроблених технологій ЗРС 6-го покоління, відсутніх у прототипах. Таким чином здійснюється створення ЗРС покоління 5+. При такому підході дуже скорочуються час і вартість розробки.

Слід відзначити також дуальний характер ЗРС у складі екосистеми. 3 однієї сторони ЗРС виступає як цільова система. Однак на етапі використання (рис. 2) сервіси і можливості ЗРС в операційному оточенні застосовуються для створення системи зенітного ракетного прикриття, тобто ЗРС виступає як забезпечуюча система. Дуальність ЗРС у свою чергу є проявом мультирозумності екосистеми. Частини такої системи прагнуть до незалежної поведінки, в той час як ціле стає все більш залежним. Це породжує дилему: що ж все-таки важливіше - 
централізація (врахування інтересів цілого) або децентралізація (врахування інтересів частин)? Подібне протиставлення веде або до концентрації влади, або до хаосу. Будь-які компроміси на основі розмежування функцій між владами приносять лише розчарування i застій. Рішення проблеми полягає в представленні, що централізація і децентралізація дві сторони однієї медалі. Вони повинні працювати одночасно [10]. На думку Акоффа спільне застосування принципів централізації і децентралізації можливо у разі делегування повноважень (а не поділу влади) і єдиних критеріях прийняття рішень. Владу як і знання можна дублювати [10].

Для екосистеми ЗРС виконання даних рекомендацій призводить до дуже цікавих наслідків. Ієрархія вирішуваних завдань призводить до формування ієрархічного набору моделей їх вирішення. В умовах використання хмарних технологій існує можливість забезпечити загальний доступ до даних, а відповідно і цим моделям. А делегування повноважень визначається наявністю відповідних компетенцій по роботі з моделями (загальні критерії прийняття рішень). Це призводить до парадоксальних результатів. Якщо модель рішення про початок ведення бойових дій спростилася до “відкрити вогонь при вході противника в зону ураження”, то фактично прийняти рішення про початок війни може лейтенант начальник розрахунку ЗРС. I навпаки, відома катастрофа 22 червня 1941 р трапилася багато в чому то- му, що модель прийняття рішення про початок війни була настільки складною, що навіть верховне керівництво країни не мало потрібними компетенціями для своєчасного прийняття рішення. Таким чином ієрархічність структури мультирозумних екосистем в рамках делегування повноважень визначається ієрархічністю і рівнями компетенцій окремих цілеспрямованих (по Акоффу) учасників команди. Соціокультурна модель побудови мультирозумних систем передбачає, що у процесі діяльності компетенції ЛПР (рис. 10) зростають, що робить структурну динаміку таких систем ще більш гнучкою.

\section{Висновки}

Індустріально розвиненими країнами в теперішній час формується нова культура створення і застосування складних систем-систем, заснована на засадах соціокультурних моделей побудови організацій і мультирозумних систем. Життєвий цикл ЗРС розглядається тепер як діяльність всіх систем забезпечення, що ведуть цільову систему від ії задуму до виведення з експлуатації. У зв'язку з чим існуючий механізм управління життєвим циклом ОВТ потребує корекції. Виникає необхідність створення інтегрованих екосистем забезпечення ЖЦ ЗРС, в яких архітектура екосистеми, а не зразок ОВТ та його життєвий цикл, виступають у якості об'єкту керування. Екосистему ЗРС потрібно розглядати як датацентричну систему.

\section{Список літератури}

1. Метод проектування системи управління життєвим циклом перспективної зенітної ракетної системи / А.Б. Скорик, М.А. Павленко, К.Г. Корнєєв, С.В. Осієвський // Наука і техніка Повітряних Сил Збройних Сил України. - 2019. № 3(36). - C. 86-92. https://doi.org/10.30748/nitps.2019.36.10.

2. Скорик А.Б. Еволюційний розвиток концепції мережево-центричних війн, системно-концептуальні основи теорії дата-центричних операцій / А.Б. Скорик, С.П. Ярош // Збірник наукових праць Харківського національного університету Повітряних Сил. - 2020. - № 4(66). - С. 26-34. https://doi.org/10.30748/zhups.2020.66.03.

3. Moore J.F. The Death of Competition: Leadership \& Strategy in the Age of Business Ecosystems / J.F. Moore. - New York: HarperBusiness, 1996. - Р. 297.

4. Методические основы системных исследований и решения проблем технического оснащения вооруженных сил государства: монография / Б.А. Демидов, О.П. Коростелев, С.Н. Остапенко, Д.А. Гриб и др. под ред. Б.А. Демидова и О.П. Коростелева. - К.: Издательский дом “Стилос”, 2016. - 655 с.

5. Системно-концептуальные основы методологии военно-научных исследований и решения прикладных военнотехнических проблем: монография / Б.А. Демидов, С.Н. Остапенко, М.И. Луханин, А.Ф. Величко, М.В. Науменко, О.А. Хмелевская, Т.И. Филякова; под ред. Б.А. Демидова. - Тверь: Стилос, 2014. - 688 с.

6. Weapon system requirements. Detailed systems engineering prior to product development positions programs for success. Report to congressional committees [Electronic resource]. - Washington: Department of Defense, 2016. - 44 p. - Available at: https://www.gao.gov/assets/690/681106.pdf.

7. The official site of OSD.MIL. Best practices for using systems engineering standards (ISO/IEC/IEEE 15288, IEEE 15288.1, and IEEE 15288.2) on contracts for Department of Defense Acquisition Programs. - Available at: https://www.acq.osd.mil/.

8. Curry E. Next-Generation Smart Environments: From System of Systems to Data Ecosystems [Electronic resource] / E. Curry, A. Sheth // IEEE Computer Society. $\quad$ - 31 July 2018. - P. 69-76. - Available at: https://ieeexplore.ieee.org/document/8423524.

9. Ota D. Modular verification and validation for NATO generic vehicle architecture-based land platforms / D. Ota // International Conference on Military Communications and Information Systems, 22-23 May 2018. https://doi: 10.1109/ICMCIS.2018.8398715/.

10. Gharajedaghi J. Systems Thinking: Managing Chaos and Complexity: A Platform for Designing Business Architecture / J. Gharajedaghi // USA, Elsevier, Inc., 2011. - P. 376. ISBN 978-0-12-385915-0. 
11. Левенчук А. Системно инженерное мышление [Електронний ресурс] / А. Левенчук. - 2015. - Режим доступу: http://techinvestlab.ru/files/systems_engineering_thinking/systems_engineering_thinking_2015.pdf.

12. Левенчук А. Системное мышление 2020 [Електронний ресурс] / А. Левенчук. - 2020. - Режим доступу: https://ridero.ru/books/sistemnoe_myshlenie/freeText.

13. Schwartz M. Defense Acquisitions: How DOD Acquires Weapon Systems and Recent Efforts to Reform the Process / M. Schwartz. - Washington D.C.: BiblioGov, 2014. - 32 c.

14. Скорик А.Б. Дата-центрична операція, принципи системо-системного мислення і концепція створення архітектурного фреймворку зенітних ракетних систем AFADS / А.Б. Скорик // Системи обробки інформації. - 2020. - № 4(163). - C. 77-86. https://doi:10.30748/soi.2020.163.08.

15. IEEE 1220-2005 - IEEE Standard for Application and Management of the Systems Engineering Process [Electronic resource]. - Geneva, 2005. - 11 p. - Available at: https:/www.sis.se/api/document/preview/909001/.

16. Héder M. From NASA to EU: the evolution of the TRL scale in Public Sector Innovation / M. Héder // The Innovation Journal: The Public Sector Innovation Journal. - 2017. - № 22(2). - P. 1-23.

17. Technology Readiness Levels Introduction [Electronic resource]. - Available at: http://as.nasa.gov/aboutus/trlintroduction.html.

18. The official site of DAU.MIL. Interim DoD Instruction 5000.02 Operation of the Defense Acquisition System. Available at: https://www.dau.mil/guidebooks/Shared\%20Documents\%20HTML/ DoDI\%205000.02.aspx.

\author{
Скорик Анатолій Борисович \\ кандидат технічних наук доцент \\ доцент кафедри Харківського національного \\ університету Повітряних Сил ім. І. Кожедуба, \\ Харків, Україна, \\ https://orcid.org/0000-0002-4327-8796
}

\author{
Anatolii Skoryk \\ Candidate of Technical Sciences Associate Professor \\ Senior Lecturer of Ivan Kozhedub Kharkiv \\ National Air Force University, \\ Kharkiv, Ukraine \\ https://orcid.org/0000-0002-4327-8796
}

\title{
МЕТОДОЛОГИЧЕСКИЕ ОСНОВЫ СОЗДАНИЯ АРХИТЕКТУРЫ ДАТА-ЦЕНТРИЧЕСКОЙ ЭКОСИСТЕМЫ ЗРС
}

\author{
А.Б. Скорик
}

В статье предложены новые подходы к управлению жизненным циклом ЗРС. Жизненный цикл системы рассматривается как деятельность всех систем обеспечения, ведущих иелевую систему от ее замысла до вывода из эксплуатации. Подчеркивается необходимость интеграции систем обеспечения в рамках дата-центрической экосистемы ЗРС. Предложенные подходы к построению архитектуры экосистемы ЗРС, разработана модель архитектуры системы интеграции и развития возможностей по созданию экосистемы ЗРС и обоснована общая структура метода создания архитектуры экосистемы ЗРС.

Ключевые слова: архитектура, архитектурный фреймворк, дата-центтрическое операция, датацентрическое система, экосистема ЗРС, система обеспечения, управление жизненным циклом, целевая система.

\section{METHODOLOGICAL FUNDAMENTALS OF CREATING THE ADS DATA-CENTRIC ECOSYSTEM ARCHITECTURE}

\section{A. Skoryk}

The article proposes new approaches to the life cycle management of an anti-aircraft missile system. The life cycle of the system is considered as the activity of all support systems that lead the target system from its design to decommissioning. It is concluded that it is necessary to correct the existing mechanism for managing the life cycle of weapons. Emphasis is placed on the need to integrate security systems within the data-centric ecosystem of ZRS. It is substantiated that the architecture of the ecosystem, and not the sample of weapons and its life cycle, act as an object of management. Approaches to construction of architecture of ADS ecosystem are offered, the model of architecture of system of integration and development of possibilities on creation of ecosystem of ADS is developed and the general structure of a method of creation of architecture of ecosystem of ADS is substantiated. It is concluded that when creating a promising ADS in Ukraine, it is advisable to use the principle of "catching up" development, which assumes that the prototype uses existing models of 5th generation ADS, design is carried out when most of the required technologies are already on the market. a base that can be applied more advanced than that used in existing 5th generation ADS. In addition, there is a possibility of partial application of the developed technologies of 6th generation ADS, which are absent in the prototypes. The main factors influencing the process of developing promising weapons are analyzed on the examples of the implementation of the program for the development of advanced weapons in the United States. Emphasis is placed on the need to use a multi-step evolutionary spiral model of ADS. With the application of this approach, the combat capabilities of the ADS increase step by step, as the technological capabilities mature.

Keywords: architecture, architectural framework, data-centric operation, data-centric system, ecosystem ADS, system maintenance, lifecycle management, targeted system. 